\title{
Chlorhexidine/Ethyl Alcohol Mouthwash
}

National Cancer Institute

\section{Source}

National Cancer Institute. Chlorhexidine/Ethyl AlcoholMouthwash. NCI Thesaurus. Code C121780.

A mouthwash containing the biguanide chlorhexidine and ethyl alcohol, with topical antibacterial activity. Upon rinsing the oral cavity with the chlorhexidine/ethyl alcohol mouthwash, the positively charged chlorhexidine cation exerts its antibacterial activity through binding to the negatively charged microbial cell surface, which destroys the integ rity of the cell membrane. This causes leakage of intracellular components leading to cell death. Ethyl alcohol denatures bacterial proteins, and dissolves and disrupts the bacterial lipid membrane, thereby killing the bacteria. This reduces oral colonization with harmful bacteria and may prevent oral mucositis. 